\title{
Effects of Draconis Resina on the Collagenase Activities and the Procollagen Synthesis in Hs68 Human Fibroblasts, and Tyrosinase Activity
}

\author{
Tae Yeon Kim, Kang-Hyun Leem \\ College of Korean Medicine, Semyung University, Jechon 390-711, Korea
}

\begin{abstract}
Objectives : Draconis Resina (DR), the resin of Daemonorops draco Bl., is used to circulate the blood and to stop bleeding. It also has been used to generate flesh including ulceration. The present study investigated the effects of DR extract on collagen metabolism in human fibroblasts and tyrosinase activity in mushroom tyrosinase.

Methods : The effect of DR extract on type I procollagen production (collagen type I synthesis) and collagenase (matrix metalloproteinase-1, henceforth referred as MMP-1) activity in human normal fibroblasts cell line. Hs68 cells after ultraviolet B (UVB, $312 \mathrm{~nm}$ ) irradiation was measured using the enzyme - linked immunosorbent assay (ELISA). The tyrosinase activity was also measured to find out the whitening effects in mushroom tyrosinase by ELISA method.

Results : There was no cytotoxicity at DR extract at concentrations of $10 \mu \mathrm{g} / \mathrm{ml}, 30 \mu \mathrm{g} / \mathrm{ml}$, and $100 \mu \mathrm{g} / \mathrm{ml}$. DR extract significantly inhibited the increase of collagenase activity, whereas it did not show on the reduction of type I procollagen in UVB damaged Hs68 cells. DR extract did not reduce the L-DOPA oxidation. However, it significantly reduced the tyrosinase activity by DR extract at concentraions of $0.1 \mathrm{mg} / \mathrm{ml}, 1 \mathrm{mg} / \mathrm{ml}$ and $10 \mathrm{mg} / \mathrm{ml}$. Conclusions : In conclusion, DR showed the anti-wrinkle and whitening effects via the inhibition of collagenase production and the tyrosinase activity. These results suggest that DR may have potential as an anti-aging ingredient in cosmetic herb markets.
\end{abstract}

Key words : Draconis Resina, Elastase, Collagenase, Collagen, Hs68, Fibroblasts

\section{Introduction}

Draconis Resina (DR) is a resin obtained from Daemonorops draco $\mathrm{Bl}$. Its effects are to activate blood circulation and relieve pain. It reduces bleeding and promotes generation of flesh in the cases of skin lesions and ulcerations ${ }^{1,2}$. The present drug was chosen from the preliminary screening tests (Data not shown).

The latest trend today is to look younger than one's age. In these days, aging seems to be treated not as an inescapable destiny to accept but as a disease or a disorder to overcome. There are two major theories of aging: the programmatic theory that aging is an inherent genetic process, and the stochastic theory that aging represents random environmental damage. Processes that are associated with cellular damage and aging are the production of free radicals (a process much enhanced after ultraviolet irradiation) and an increasing number of errors during DNA replication. Cellular manifestations of intrinsic aging include decreased life span of cells, decreased responsiveness of cells to growth signals, which may reflect loss of cellular receptors for growth factors, and increased responsiveness to growth inhibitors. All these findings are more pronounced in cells derived from photodamaged skin ${ }^{3)}$.

It has been shown that UV irradiation leads to the formation of reactive oxygen species (ROS) that activate the mitogen-activated protein (MAP) kinase pathway, which subsequently induces the expression and activation of matrix metalloproteinases (MMPs) in human skin in vivo $^{4,5)}$. MMPs including collagenase are considered key factors in the photoaging process.

$\mathrm{DR}$ is traditionally used in the recovery of skin

\footnotetext{
*Corresponding author : Kang-Hyun Leem. College of Korean Medicine, Semyung University, Jechon 390-711, Korea

· Tel : +82-43-649-1341 · E-mail : lkh@semyung.ac.kr

\#First author : Tae Yeon Kim. College of Korean Medicine, Semyung University, Jechon 390-711, Korea

· Tel : +82-43-649-1339 · E-mail : violet805@ hanmail.net

- Received : 13 October 2015 - Revised : 16 November 2015 - Accepted : 16 November 2015
} 
lesions. It might prefigure the modern pharmacological anti-wrinkle effects of DR.

In the present study, we investigated the effect of DR on the changes of type I procollagen production and collagenase activity in human normal fibroblasts Hs68 after UVB irradiation. We also measured the tyrosinase activity in mushroom tyrosinase after treatment of DR.

\section{Materials and Methods}

\section{Sample preparation}

Draconis Resina was purchased from Omniherb (Korea). Draconis Resina extracts (DR) was prepared as follow. $100 \mathrm{~g}$ of Draconis Resina in 2,000 ml distilled water was heated in a heating extractor for 3 hours. The extract was filtered and concentrated by using the rotary evaporator. The extracts were lyophilized by using freeze dryer $(10.3 \mathrm{~g})$. The extract was dissolved in water and filtered three times through micro-filter paper and syringe filter (Whatman \#2, $0.45 \mu \mathrm{m}$ to $0.2 \mu \mathrm{m}$ ). Filtered material was placed in the disinfected vial and was sealed for further study.

\section{Cell culture}

Hs68 human fibroblasts (Health Protection Agency Culture Collections, UK) were cultured in Dulbecco's Modified Eagle's medium (Gibco, USA) containing 10\% fetal bovine serum, $1 \%$ antibiotics at $37^{\circ} \mathrm{C}$ in a humidified atmosphere of $5 \% \quad \mathrm{CO}_{2}$. When cells reached above confluency (70-80\%), subculture was conducted at a split ratio of $1: 3$.

\section{UVB irradiation}

A UVB lamp (Vilber Lourmat, France) was used as a UVB source. In brief, Hs68 cells were rinsed twice with phosphate-buffered saline (PBS, Sigma-Aldrich, USA), and all irradiations were performed under a thin layer of PBS ( $200 \mu \mathrm{l} /$ well of 24 well plate). Immediately after irradiation $\left(100 \mathrm{~mJ} / \mathrm{cm}^{2}\right)$, fresh serum-free medium was added to the cells. After 24 hours incubation period, responses were measured. Mock-irradiated blanks followed the same schedule of medium changes without UVB irradiation.

\section{Cell viability}

General viability of cultured cells was determined by reduction of $3-(4,5-$ dimethylthiazol-2-yl $)-2,5-$ diphenyltetrazolium bromide (MTT, Sigma-Aldrich, USA) to formazan. The human fibroblast cells (Hs68) were seeded in $24-$ well plates at a density of $2 \times 10^{5} / \mathrm{ml}$ per well and cultured at $37^{\circ} \mathrm{C}$ in $5 \% \quad \mathrm{CO}_{2}$. Cells were pretreated with the sample at a concentration of 10 , 30, and $100 \mu \mathrm{g} / \mathrm{ml}$ for 24 hours prior to UVB irradiation. After UVB irradiation, cells were retreated with the sample and incubated for additional 24 hours, before being treated with $0.05 \mathrm{mg} / \mathrm{ml}$ (final concentration) of MTT. The blank and control group was cultivated without sample treatment. The cells were then incubated at $37^{\circ} \mathrm{C}$ for additional $4 \mathrm{~h}$. The medium containing MTT was discarded, and MTT formazan that had been produced was dissolved with $200 \mu \mathrm{l}$ of dimethyl sulfoxide (DMSO, Sigma-Aldrich, USA). The absorbance was read at $595 \mathrm{~nm}$ with a reference wavelength of 690 $\mathrm{nm}$. The cell viability being calculated as follows:

Cell viability (\%)

$=[($ OD595 of sample $) /($ OD595 of control $)] \times 100$

\section{Assays of collagen type I synthesis and} collagenase inhibition

Hs68 human fibroblasts were inoculated into 24-well plate $\left(2 \times 10^{5}\right.$ cells/well, Sigma-Aldrich, USA) and cultured at $37^{\circ} \mathrm{C}$ in $5 \% \mathrm{CO}_{2}$. Cells were pretreated with the sample at a concentration of 10,30 , and 100 $\mu \mathrm{g} / \mathrm{ml}$ for 24 hours prior to UVB irradiation. After UVB irradiation, cells were retreated with the sample and incubated for additional 24 hours. The blank and control group was cultivated without sample treatment. After culturing, the supernatant was collected from each well, and the amount of pro-collagen type I was measured with a procollagen type I C-peptide assay kit (Takara Bio, Japan). The activity of collagenase was measured with a MMP-1 human biotrak ELISA system (Amersham life science, USA).

\section{Tyrosinase inhibition assay}

Tyrosinase activity was determined essentially as previously described ${ }^{6)}$. The reaction mixtures were prepared by adding $40 \mathrm{U}$ of mushroom tyrosinase (Sigma-Aldrich, USA) to $20 \mu \mathrm{l}$ of DR dissolved in distilled water $(0.1,1$, and $10 \mathrm{mg} / \mathrm{ml})$, and then adding $40 \mathrm{\mu l}$ of $1.5 \mathrm{mM}$ L-tyrosine (Sigma-Aldrich, USA) and $220 \mu \mathrm{l}$ of $0.1 \mathrm{M}$ sodium phosphate buffer ( $\mathrm{pH}$ 6.5). The resulting mixture $(300 \mu \mathrm{l})$ was incubated for $10 \mathrm{~min}$ at $37^{\circ} \mathrm{C}$ and then absorbance at $490 \mathrm{~nm}$ was measured. The same mixture, but without DR extract, was used as a control. 


\section{Inhibition of L-DOPA oxidation}

The inhibitory effect of DR on L-DOPA oxidation was determined according to the method of Joshi with a slight modification ${ }^{7)}$. $50 \mu \mathrm{l}$ of $\mathrm{DR}$ dissolved in $0.1 \mathrm{M}$ sodium phosphate buffer $(0.1,1$, and $10 \mathrm{mg} / \mathrm{ml})$ was added to $40 \mathrm{U}$ of mushroom tyrosinase in $900 \mu \mathrm{l}$ of $0.1 \mathrm{M}$ sodium phosphate buffer ( $\mathrm{pH}$ 6.5). After $6 \mathrm{~min}$ of incubation at $37^{\circ} \mathrm{C}, 3 \mathrm{mM}$ of L-DOPA (SigmaAldrich, USA) was added. Then the mixture was incubated at $37^{\circ} \mathrm{C}$ for $15 \mathrm{~min}$. Activities were quantified by measuring absorbance at $475 \mathrm{~nm}$. The same mixture, but without DR extract, was used as a control.

\section{Statistical analysis}

The results were expressed as means \pm standard error of the mean (SEM). Significances of changes were evaluated using the one-way ANOVA with Dunnett's post-hoc test. Values of $p<0.05$ were considered significant.

\section{Results}

\section{Cytotoxicity of DR on Hs68 fibroblasts}

To evaluate the cytotoxicity of DR extract in Hs68 cells, the extract was treated at 10, 30, and $100 \mu \mathrm{g} / \mathrm{ml}$. The cell viability was determined by MTT assay, and calculated into $100 \%$ of control group. The cell viabilities were $92.9 \pm 1.4 \%$ in $\mathrm{DR}$ extract at $10 \mu \mathrm{g} / \mathrm{ml}, 91.9 \pm$ $0.9 \%$ in $\mathrm{DR}$ extract at $30 \mathrm{\mu g} / \mathrm{ml}$, and $95.7 \pm 2.8 \%$ in $\mathrm{DR}$ extract at $100 \mathrm{\mu g} / \mathrm{ml}$. As a result, DR extract showed no cytotoxicity up to the $100 \mu \mathrm{g} / \mathrm{ml}$ (Fig. 1).

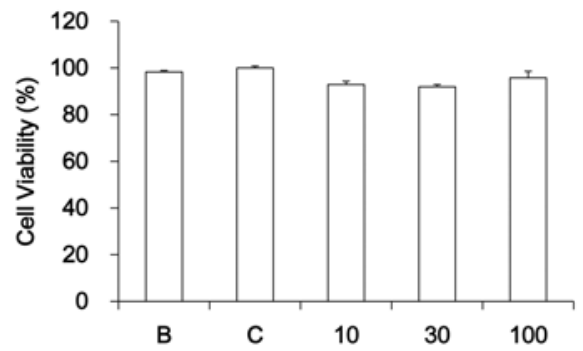

Fig. 1. Cell viability of DR extract in Hs68 cells. Cell viability was measured by MTT assay, and calculated the viability on $\%$ of control. B: blank, distilled water treated group without UVB irradiation. C: control, distilled water treated group with UVB irradiation. 10, 30, and 100: Draconis Resina extracts (DR 10, 30, and $100 \mu \mathrm{g} / \mathrm{ml}$ ) treated group. Data are expressed as the mean \pm SEM of three experiments.

\section{Effect of DR extract on collagen type I}

\section{synthesis in Hs68 fibroblasts}

To evaluate the amount of collagen type I synthesis that occurred upon exposure to the extract, collagen type I was quantitatively detected by using the procollagen type I C-peptide assay kit. As shown in Figure 2. The collagen concentration was $16.7 \pm 0.3 \mathrm{ng} / \mathrm{ml}$ in $\mathrm{DR}$ extract at $10 \mu \mathrm{g} / \mathrm{ml}, 17.3 \pm 0.6 \mathrm{ng} / \mathrm{ml}$ in $\mathrm{DR}$ extract at $30 \mu \mathrm{g} / \mathrm{ml}$, and $14.2 \pm 0.3 \mathrm{ng} / \mathrm{ml}$ in $\mathrm{DR}$ extract at $100 \mu \mathrm{g} / \mathrm{ml}$. As a result, DR extract did not increase the collagen production.

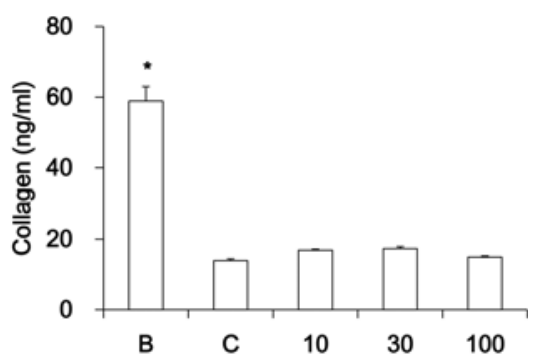

Fig. 2. Effect of DR extract on collagen type I synthesis in Hs68 cells. The concentration of collagen type I synthase was measured in supernatant by ELISA method. B: blank, distilled water treated group without UVB irradiation. C: control, distilled water treated group with UVB irradiation. 10, 30, and 100: Draconis Resina extracts (DR 10, 30, and $100 \mathrm{mg} / \mathrm{ml}$ ) treated group. Data are expressed as the mean \pm SEM of three experiments. ${ }^{*}$ : significantly different from the control, $p<0.05$

\section{Effect of DR extract on collagenase activity}

\section{in Hs68 fibroblasts}

To evaluate the collagenase activity, MMP-1 activity was quantitatively measured in cell lysates by MMP-1 assay kit. The activities of MMP-1 by the treatment of DR extract were calculated into $100 \%$ of control group (Fig. 3). DR extract significantly reduced the MMP-1 activity with $33.2 \pm 3.1 \%$ at $10 \mu \mathrm{g} / \mathrm{ml}$, with $15.3 \pm$ $8.0 \%$ at $30 \mu \mathrm{g} / \mathrm{ml}$, and with $7.8 \pm 0.4 \%$ at $100 \mu \mathrm{g} / \mathrm{ml}$.

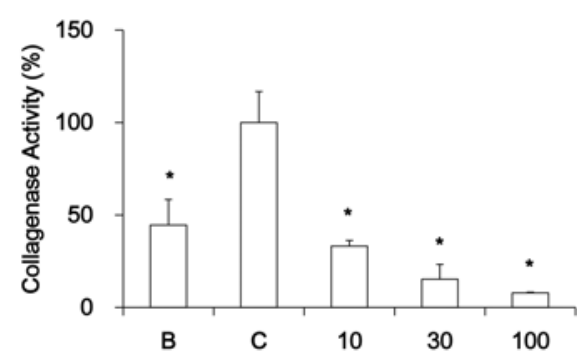

Fig. 3. Effect of DR extract on collagenase activity in Hs68 cells. Collagenase activity was measured in cell lysates by ELISA method. B: blank, distilled water treated group without UVB irradiation. C: control, distilled water treated group with UVB irradiation. 10, 30, and 100: DR extracts $(10,30$, and $100 \mathrm{mg} / \mathrm{ml})$ treated group. Data are expressed as the mean \pm SEM of three experiments. : : significantly different from the control, $p<0.05$.

\section{Inhibitory effects of DR extract on tyrosinase} activity in mushroom tyrosinase

Tyrosinase activities were measured in mushroom tyrosinase by ELISA method. The activities of DR extract 
on tyrosinase activity was calculated into $100 \%$ of control group(Fig. 4). DR extract significantly reduced the tyrosinase activity at concentrations of $0.1,1$ and $10 \mathrm{mg} / \mathrm{ml}(21.8 \pm 17.2 \%, 6.6 \pm 7.8 \%$ and $1.0 \pm 0.5 \%$, $p<0.05$, respectively).

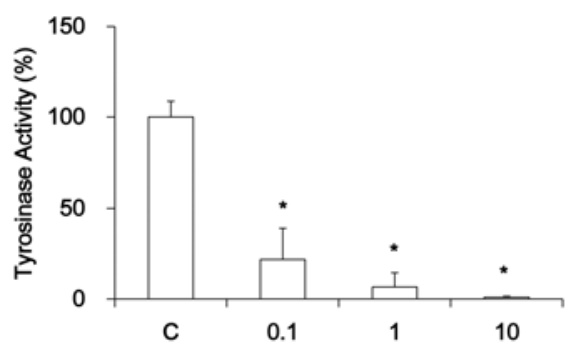

Fig. 4. Effect of DR extract on tyrosinase activity. Tyrosinase activities were measured in mushroom tyrosinase by ELISA method. C: control, distilled water treated group. 0.1, 1, and 10: DR extracts $(0.1,1$, and $10 \mathrm{mg} / \mathrm{ml})$ treated group. Data are expressed as the mean \pm SEM of three experiments. : significantly different from the control, $p<0.05$.

\section{Inhibitory effects of DR extract on L-DOPA}

\section{oxidation in mushroom tyrosinase}

L-DOPA oxidation activities were measured in mushroom tyrosinase by ELISA method. The activities of DR extract on L-DOPA oxidation were calculated into $100 \%$ of control group(Fig. 5). DR extract at $0.1,1$ and $10 \mathrm{mg} / \mathrm{ml}$ did not show any inhibitory activities in L-DOPA oxidation $(72.6 \pm 24.0 \%, 96.9 \pm 18.7 \%$ and $88.4 \pm 24.9 \%$ respectively).

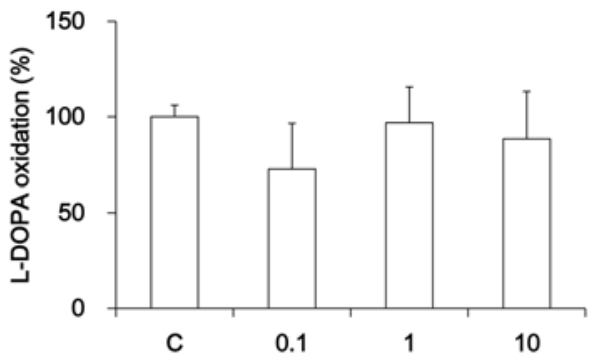

Fig. 5. Effect of DR extract on L-DOPA oxidation. L-DOPA oxidation activities were measured in mushroom tyrosinase by ELISA method. C: control, distilled water treated group. 0.1, 1 , and 10: DR extracts $(0.1,1$, and $10 \mathrm{mg} / \mathrm{ml})$ treated group. Data are expressed as the mean \pm SEM of three experiments.

\section{Discussion}

Draconis Resina is a resin (Daemonorops draco $\mathrm{Bl}.)^{1)}$. It is mainly used for external usage to stop bleeding and to promote the generation of flesh. Topical application treats both acute and chronic skin conditions. It stops bleeding in acute conditions, and promotes the healing of wounds in chronic conditions by facilitation the generation of flesh and prevents the spread of uncerations. It is also orally taken to activate blood circulation, to remove blood stasis, and to relieve pain. The internal use of DR treats both acute and chronic blood stasis, swelling, and pain ${ }^{1,2)}$.

The skin aging is one of the most obvious evidence of aging. The skin is increasingly exposed to ambient UV-irradiation thus increasing risks for photooxidative damage with long-term detrimental effects like photoaging, characterized by wrinkles, loss of skin tone and resilience. Photoaged skin displays alterations in the cellular component and extracellular matrix with accumulation of disorganized elastin and its microfibrillar component fibrilin in the deep dermis and a severe loss of interstitial collagens, the major structural proteins of the dermal connective tissue. It has been shown that UV irradiation leads to the formation of reactive oxygen species (ROS) that activate the mitogen-activated protein (MAP) kinase pathway, which subsequently induces the expression and activation of MMPs in human skin in vivo $^{4,5)}$. MMPs are known to be over-expressed in human fibroblasts within hours after exposure to UV irradiation. Therefore, MMPs are considered key regulators in the photoaging process. Inhibiting the major collagendegrading enzymes like MMPs would be a useful agents for anti-aging.

In order to evaluate the cytotoxicity of DR, samples were prepared at various concentrations and used to treat human fibroblasts (Hs68). There was no cytotoxicity in all treated concentrations. The cells treated by DR $300 \mathrm{\mu g} / \mathrm{ml}$ showed a slight cytotoxicity.

Collagens are synthesized as precursor molecules, called procollagens. These molecules contain additional peptide sequences, usually referred to as 'propeptides', at both the amino-terminal end and the carboxyterminal end. These propeptides are cleaved from the collagen triple-helix molecule during its secretion, after which the triple-helix collagens are polymerized into extracellular collagen fibrils. Thus, the amount of free propeptide stoichiometrically reflects the amount of collagen molecules synthesized ${ }^{8)}$. Collagen is a group of naturally occurring proteins. In nature, it is found exclusively in animals, especially in the flesh and connective tissues of mammals ${ }^{9}$. It is the main component of connective tissue, and is the most abundant protein in mammals, making up about $25 \%$ to $35 \%$ of the whole-body protein content $^{10)}$. Collagen, in the form of elongated fibrils, is mostly found in fibrous tissues such as tendon, ligament and skin, and is also abundant in cornea, cartilage, bone, blood vessels, the gut, and intervertebral disc. In muscle tissue it serves as a major component of endomysium. Collagen constitutes $1 \%$ to $2 \%$ of muscle tissue, and accounts for $6 \%$ of the weight of strong, tendinous muscles ${ }^{11)}$. Collagen occurs in many places throughout the body. So far, 
only 29 types of collagen have been identified and described. Over $90 \%$ of the collagen in the body, however, is of type I, II, III, and IV. Among them, collagen type I is placed at skin, tendon, vascular, ligature, organs, and bone (main component of bone). Collagen-related diseases most commonly arise from genetic defects or nutritional deficiencies that affect the biosynthesis, assembly, postranslational modification, secretion, or other processes involved in normal collagen production. In this study, the amount of collagen type I was slightly increased at all concentrations of DR. However, there was no statistical significance.

To evaluate the collagenase activity, MMP-1 activity was quantitatively measured. DR significantly reduced the MMP-1 activity at all concentrations in a dose dependent manner. The $\mathrm{MMP}-1$ reducing activities at 30 and $100 \mu \mathrm{g} / \mathrm{ml}$ are below the activity of blank group. It might be thought that DR might inhibited the naturally induced collagenase activity as well.

The activities of DR on tyrosinase activity were significantly effective at $0.1,1$ and $10 \mathrm{mg} / \mathrm{ml}$.

\section{Conclusion}

In this study, I determined the amounts of type I collagen synthesis and collagenase activity. And the tyrosinase activity and L-DOPA oxidation were measured in DR-treated groups.

1. DR showed no cytotoxicity up to the effective concentration for the measuring the amounts of type I collagen synthesis and collagenase activity in Hs68 cells.

2. The collagen amounts of DR $10 \mu \mathrm{g} / \mathrm{ml}, 30 \mu \mathrm{g} / \mathrm{ml}$ and $100 \mu \mathrm{g} / \mathrm{ml}$ treated group did not increase.

3. DR significantly reduced the $\mathrm{MMP}-1$ activity at concentrations of $10 \mu \mathrm{g} / \mathrm{ml}, 30 \mu \mathrm{g} / \mathrm{ml}$, and 100 $\mu \mathrm{g} / \mathrm{ml}$ in a dose dependent manner.

4. DR significantly reduced the tyrosinase activity at concentrations of $0.1 \mathrm{mg} / \mathrm{ml}, 1 \mathrm{mg} / \mathrm{ml}$ and 10 $\mathrm{mg} / \mathrm{ml}$ in a dose dependent manner.

5. DR $0.1 \mathrm{mg} / \mathrm{ml}, 1 \mathrm{mg} / \mathrm{ml}$ and $10 \mathrm{mg} / \mathrm{ml}$ treated groups did not show any inhibitory activity in L-DOPA oxidation.

These results suggest that DR may have potential as an anti-aging ingredient in cosmetic herbal drugs. I think further studies will be needed to unravel exactly under the molecular mechanisms.

\section{Acknowledgement}

This work was carried out with the support of "Cooperative Research Program for Agriculture Science \& Technology Development (Project No. PJ010181)" Rural Development Administration, Republic of Korea.

\section{References}

1. Kim IR, Kim HC, Kuk YB, Park SJ, Park YK, Park JH, Seo BI, Seo YB, Song HJ, Shin MK, Lee YJ, Lee YC, Lee JH, Leem KH, Cho SI, Chung JK, Joo YS, Choi HY. Boncho-Hak. Seoul : Young-Lim Press. 1999 : 441-2.

2. Chen JL, Chen TT. Chinese Medical Herbology and Pharmacology. CA : Art of Medicine Press. 2004 : 853-5.

3. Yaar M, Gilchrest BA. Cellular and molecular mechanisms of cutaneous aging. J Dermatol Surg Oncol. 1990 ; 16(10) : 915-22.

4. Fisher GJ, Datta SC, Talwar HS, Wang ZQ, Varani J, Kang S, Voorhees JJ. Molecular basis of sun-induced premature skin ageing and retinoid antagonism. Nature. 1996 ; 379(6563) : 335-9.

5. Shin JY, Hur W, Wang JS, Jang JW, Kim CW, Bae SH, Jang SK, Yang SH, Sung YC, Kwon OJ, Yoon SK. HCV core protein promotes liver fibrogenesis via up-regulation of CTGF with TGF-beta1. Exp Mol Med. 2005 ; 37(2) : 138-45.

6. Vanni A, Gastaldi D, Giunata G. Kinetic investigations on the double enzyme activity of the tyrosinase mushroom. Ann Chim. 1990 ; 80 : 35-60.

7. Joshi PC, Carraro C, Pathak MA. Involvement of reactive oxygen species in the oxidation of tyrosine and dopa to melanin and in skin tanning. Biochem Biophys Res Commun. 1987 ; 142(1) : 265-74.

8. Kim YH, Chung CB, Kim JG, Ko KI, Park SH, Kim JH, Eom SY, Kim YS, Hwang YI, Kim KH. Anti-wrinkle activity of ziyuglycoside I isolated from a Sanguisorba officinalis root extract and its application as a cosmeceutical ingredient. Biosci Biotechnol Biochem. 2008 ; 72(2) : 303-11.

9. Müller WEG. The Origin of Metazoan Complexity: Porifera as Integrated Animals. Integr Comp Biol. 2003 ; 43(1) : 3-10.

10. Di Lullo GA, Sweeney SM, Korkko J, Ala-Kokko L, San Antonio JD. Mapping the ligand-binding sites and disease-associated mutations on the most abundant protein in the human, type I collagen. J Biol Chem. 2002 ; 277(6) : 4223-31. 
11. Sikorski ZE. Chemical and Functional Properties of Food Proteins. Boca Raton : CRC Press. 2001 : 242. 